\title{
Project Risk Management: Challenge Established Practice
}

\author{
Ole Jonny Klakegg \\ Department of Civil and Transport Engineering, Norwegian University of Science and Technology, \\ Høgskoleringen 1, 7491 Trondheim, Norway; ole.jonny.klakegg@ntnu.no
}

Received: 19 December 2016; Accepted: 19 December 2016; Published: 21 December 2016

The idea behind this Special Issue is based on the observation that project risk management is presented as a key knowledge area in project management and has become an important skill for updated project managers [1,2]. It has been around for more than three decades and there are numerous commercial tools available. Still, projects are delivered too late, over budget and often with less benefit than expected [3-5].

Project management, including risk management, has improved significantly but project success rates have failed to improve at the same rate [6]. Attained improvements are also seen to deteriorate remarkably quickly [7], and the development is topped with real dilemmas [8]. Johansen, Sandvin, Torp and Økland [9] identified five specific challenges in uncertainty analysis indicating that even professional risk managers and their teams do not have the right competences, adequate planning data or effective procedures to properly identify risks and uncertainties, quantify and analyze them, communicate them to decision makers or take the consequences into their project management. This clearly indicates that current practices need to be challenged.

Authors from all over the world responded to the call for papers to this Special Issue, although not all suggested contributions made it into the final result. The selected papers challenge current practices on a wide range of aspects of project risk management and in different ways:

Lichtenberg [10] describes successful research results from almost three decades ago, which successfully challenge the problems that conventional management has with handling risk in cost estimation and budgeting. The reported results have led to new and improved practices. The research involved is an unusual mix from psychology, statistical theory and engineering economy. This mix tells us about the complex and multidisciplinary nature of uncertainty management. The resulting experiences are reported, focusing on two recent studies, each of 40 infrastructures, and other major projects. In both datasets, the actual final cost largely equaled the expected project cost. This result is a marked change from international past and present experience. The principles that Lichtenberg promotes help researchers better understand the nature of cost estimation under uncertainty and practitioners can draw help from useful guidelines in this paper to improve their project risk management.

Johansen, Eik-Andresen, Landmark, Ekambaram, and Rolstadås [11] challenge the clear tendency in project risk management to focus on the negative aspects of uncertainty. Although uncertainty management theory has become well established, the authors suggest that it does not fully address why opportunities often remain unexploited. Despite theory that holds risk and opportunities to be equally important, empirical studies show a stronger focus on mitigating risks than exploiting opportunities. Several empirical studies reported in this paper indicate that even within organizations with seemingly high awareness of best practices in the field of project risk management, potential is lost. There is an obvious gap between what theory tells us and what people tend to do in practice. The authors then present a theoretical model that explains why opportunities remain unexploited. They show that the threshold for pursuing a potential opportunity is high and identify several fundamental reasons for resistance. This should potentially be of great help for practitioners in pursuit of an improved success 
rate and benefits in investment projects. It also contributes to building theory for designing decision making on complex projects.

Torp and Klakegg [12] directly tackle the list of challenges previously identified by Johansen, Sandvin, Torp and Økland [9]. Reporting on a single case study, they describe practical guidelines and share experience from cost estimation and uncertainty analyses that help mitigate many of the identified challenges in current project risk management practice. The single case is a unique insight into an extremely complex project: decommissioning of Barsebäck Nuclear Power Plant. The paper includes an adequate level of detail to make it possible for practitioners to actually take up and put into use several of the practical working procedures used in this case. The authors illustrate the importance of combining project risk management competence with professional knowledge of the actual contents of the project itself. Good preparations and planning is vital to the quality of the process that follows. The analysis involves a group of experts in a structured group process. Professional facilitation and effective communication are two key enablers for enhancing the ability to identify, evaluate, analyze and respond adequately to the steering signals found in the uncertainty analysis.

Walker and Lloyd-Walker [13] take an even closer look at team collaboration in their paper on using risks and an uncertainty based perspective in analyzing integrated project delivery forms. The authors help readers to better understand how complex projects may be understood and successfully managed. Based on interviews with 50 subject matter experts, they have developed a relationship-based procurement (RBP) framework and a tool in the form of a visual map. These results help practitioners cope by using visualization and sense-making mechanisms. The paper also extends theory by taking RBP to the next step, from pure procurement into a risk-uncertainty project management domain. Practitioners will find these ideas helpful in managing risks, uncertainty and ambiguity in their complex projects.

All these contributions have one thing in common: They all illustrate that project risk management may be led into a dead end if theory and practice keep focusing on models, data processing, decision making algorithms, procedures and tools. The risk focus needs to be balanced out with focusing on opportunities, even if it is difficult and requires extra effort. The real challenges are in the head of the individuals involved. They need help to understand, analyze and adequately respond. All contributions offer, in their own way, a piece of this puzzle.

My simple conclusion is: It is all about people and competence!

The contributors have one more thing in common-they have all previously collaborated in research or publications together in different constellations. There is a close relation between the ways in which risk and uncertainty are understood and presented in these papers. This will hopefully build a picture that helps the readers to take the next step, be it theoretical or practical guidelines or simply intriguing examples that are needed. All these are present in the current Special Issue.

Conflicts of Interest: The authors declare no conflict of interest.

\section{References}

1. PMI. Project Management Body of Knowledge; Project Mangement Institute: Newtown Square, PA, USA, 2013.

2. International Organization for Standardization (ISO). ISO 21500:2012—Guidance on Project Management. 1 September 2012. Available online: http:/ / www.iso.org/iso/catalogue_detail?csnumber=50003 (accessed on 14 December 2016).

3. Flyvbjerg, B.; Holm, M.S.; Buhl, S. Underestimating cost in public works projects. Error or lie? J. Am. Plan. Assoc. 2002, 68, 279-295. [CrossRef]

4. Ansar, A.; Flyvbjerg, B.; Budzier, A.; Lunn, D. Should we build more large dams? The actual costs of hydropower megaproject development. Energy Policy 2014, 69, 43-56. [CrossRef]

5. Olaniran, O.J.; Love, P.E.D.; Edwards, D.; Olatunji, O.A.; Matthews, J. Cost Overruns in Hydrocarbon Megaprojects: A Critical Review and Implications for Research. Proj. Manag. J. 2015, 46, 126-138. [CrossRef]

6. Mir, F.A.; Pinnington, A.H. Exploring the value of project management: Linking Project Management Performance and Project Success. Int. J. Proj. Manag. 2014, 32, 202-217. [CrossRef] 
7. Klakegg, O.J.; Williams, T.; Shiferaw, A.T. Taming the 'trolls': Major public projects in the making. Int. J. Proj. Manag. 2016, 34, 282-296. [CrossRef]

8. Klakegg, O.J.; Torp, O.; Austeng, K. Good and Simple: A dilemma in Analytical Processes? Int. J. Manag. Proj. Bus. 2010, 3, 402-421. [CrossRef]

9. Johansen, A.; Sandvin, B.; Torp, O.; Økland, A. Uncertainty analysis- 5 challenges with today's practice. Proced. Soc. Behav. Sci. 2014, 119, 591-600. [CrossRef]

10. Lichtenberg, S. Successful Control of Major Project Budgets. Adm. Sci. 2016, 6, 8. [CrossRef]

11. Johansen, A.; Eik-Andresen, P.; Dypvik Landmark, A.; Ekambaram, A.; Rolstadås, A. Value of Uncertainty: The Lost Opportunities in Large Projects. Adm. Sci. 2016, 6, 11. [CrossRef]

12. Torp, O.; Klakegg, O.J. Challenges in Cost Estimation under Uncertainty-A Case Study of the Decommissioning of Barsebäck Nuclear Power Plant. Adm. Sci. 2016, 6, 14. [CrossRef]

13. Walker, D.; Lloyd-Walker, B. Understanding Collaboration in Integrated Forms of Project Delivery by Taking a Risk-Uncertainty Based Perspective. Adm. Sci. 2016, 6, 10. [CrossRef]

(C) 2016 by the author; licensee MDPI, Basel, Switzerland. This article is an open access article distributed under the terms and conditions of the Creative Commons Attribution (CC-BY) license (http://creativecommons.org/licenses/by/4.0/). 